\title{
Apoteker Berperan Penting dalam Membantu Masyarakat Menurunkan Biaya Terapi
}

\author{
Maria Maretta \\ Fak ultas Farmasi, Universitas Sanata Dharma, Sleman, Yogyakarta \\ Terbit online : 3 Desember 2016
}

\section{Abstrak :}

Bagaimana pemahaman masyarakat ketika mendengar kata apoteker? Sebuah pandangan konservatif hadir pada publik yang mengklasifikasikan apoteker sebagai pekerjaan yang tidak jauh dari istilah 'tukang obat', yang menjual dan memberikan obat kepada orang yang sakit Salah satu penelitian terkait farmakoekonomi yang dilakukan oleh Maxwell, et al (2013) terkait perbandingan antara Pharmaceutical Care (PC) yang lebih mengutamakan patient-care dalam penata laksanaan Diabetes Tipe 2 dengan Usual Care (UC) yang merupakan suatu pengobatan dengan minimnya peranan apoteker sebagai tenaga kesehatan membuktikan bahwa PC memiliki biaya terapi yang lebih murah dibanding UC. Peran apoteker dalam PC memegang peranan penting sebagai upaya peningkatan kualitas hidup pasien melalui terapi yang lebih costeffectiveness dari segi farmakoekonomi khususnya untuk penatalaksanaan pada penyakit degeneratif.

Keyword: Apoteker, Pharmaceutical Care, Usual Care, Diabetes Tipe 2

\section{Pendahuluan}

Salah satu penelitian terkait farmakoekonomi yang dilakukan oleh Maxwell, et al (2013) terkait perbandingan antara Pharmaceutical Care (PC) yang lebih mengutamakan patient-care dalam penata laksanaan Diabetes Tipe 2 dengan Usual Care (UC) yang menupakan suatu pengobatan dengan minimnya peranan apoteker sebagai tenaga kesehatan membuktikan bahwa PC memiliki biaya terapi yang lebih murah dibanding UC.

\section{Perbedaan PC dan UC}

Usual Care (UC) lebih berbasis drug oriented atau minimnya peran apoteker dalam melakukan pendekatan terhadap pasien terkait memonitoring outcome pasien dan sebatas menjual atau memberikan obat saja. Sehingga UC dapat diartikan sebagai istilah yang digunakan untuk menggambarkan praktik pelayanan kesehatan kepada pasien dimana tenaga kesehatan kurang memiliki andil yang besar untuk mencapai tujuan terapi pasien. PC disini dilakukan oleh seorang apoteker yang bekerja sama dengan dokter maupun tenaga kesehatan lainnya.

PC disini dilakukan oleh seorang apoteker yang bekerja sama dengan dokter maupun tenaga kesehatan lainnya. Mereka berkonstribusi dalam meningkatkan kualitas hidup pasien, tidak hanya sekedar memberikan suatu obat namun juga memberikan informasi serta edukasi kepada pasien, dengan terbuka menjawab pertanyaan yang diajukan pasien, serta memantau hasil terapi pasien selama menjalani terapi pengobatan (monitoring) sehingga ketika terdapat suatu kondisi diluar dari tujuan terapi dapatsegera diatasi. 


\section{Pasien dengan UC memiliki risiko ketidakpatuhan yang lebih besar}

Pasien dengan UC memiliki risiko ketidakpatuhan yang lebih besar dibandingkan dengan PC sehinggga kemungkinan besar efek terapi pengobatan tidak tercapai atau tidak dirasakan oleh pasien. Hal ini menyebabkan pengobatan yang dijalani pasien terasa sia-sia dan hanya membuang biaya sehingga tidak cost-effectiveness.

Suatu metode analisis utilitas biaya (Cost Utility Analysis) merupakan metode farmakoekonomi yang digunakan untuk membantu membuat keputusan dengan membandingkan obat ataupun program yang berbeda menggunakan parameter perbandingan antara biaya dan efektivitas serta manfaat berdasarkan penurunan mortalitas dan morbiditas.

Nilai utilitas dilihat dari tingkat kepuasan yang diperoleh pasien setelah mendapatkan intervensi pelayan kesehatan. Hasil intervensi dinyatakan dalam suatu satuan unit utilitas yang dalam kajian farmakoekonomi biasa disebut sebagai Quality Adjusted Life Years (QALY).

Hasil metode analisis utilitas biaya yang dinilai lebih cost-effectiveness dapat dijadikan suatu acuan dalam mengambil keputusan untuk mempertimbangkan intervensi yang dinila paling efektif dalam hal biaya untuk mendapatkan QALY.

Menurut penelitian Maxwell, et al (2013) dalam jurnalnya menyatakan bahwa intervensi dengan menggunakan PC menyebabkan kenaikan biaya tambahan (incremental cost) sebesar Nigerian naira (NGN) 10,623 (\$69) serta peningkatan efek sebesar 0,12 QALY, peningkatan efek sebesar 0,12 QALY, dengan kata lain dibutuhkan utilitas biaya sebesar NGN 88,525 (\$571) per satuan QALY. Pada kurva Cost-effectiveness acceptability, probabilitas menggunakan PC lebih costeffectiveness daripada UC sebesar 95\% dengan biaya threshold sebesar NGN 250,000 (\$1613) per satuan QALY dan $52 \%$ lebih cost-effectiveness dengan biaya threshold sebesar NGN 88,600 (\$572) per QALY. Oleh karena itu dapat disimpulkan bahwa pemberian intervensi dengan menggunakan PC jauh lebih cost-effectiveness dibandingkan UC dengan estimasi $\$ 571.13$ per QALY, yang berarti untuk meningkatkan kualitas hidup satu pasien yang menggunakan PC, pasien akan menghemat biaya dengan estimasi sebesar \$571.13 (Rp 7.707.399,-) dibandingkan dengan menggunakan UC.

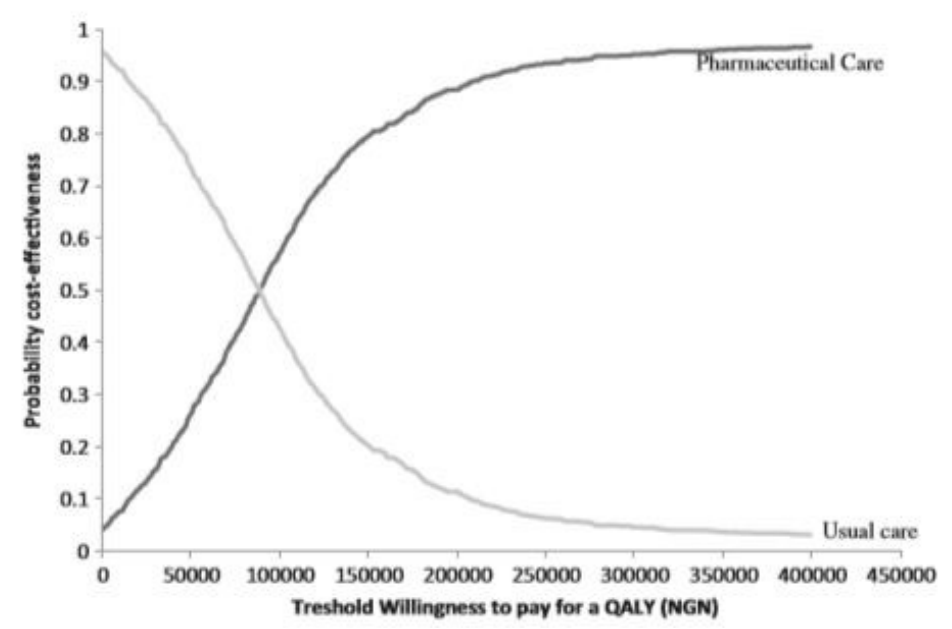

Gambar 1. Cost-effectiveness acceptability curves (Maxwell, etal (2013)) 


\section{Penelitian di Indonesia terkait biaya terapi}

Pesatnya perkembangan ilmu pengetahuan kedokteran dan farmasi diikuti dengan semakin meningkatnya kecerdasan masyarakat, semakin gencarnya promosi/iklan obat melalui media massa dan tingginya biaya pelayanan kesehatan, membuat masyarakat lebih cenderung untuk memilih UC.

Namun dalam praktiknya, masyarakat tidak hanya menggunakan obat bebas dan bebas terbatas Over The Counter (OTC) tetapi juga menggunakan obat-obatan keras sebagai regimen terapi suatu penyakit. Data Survei Sosial Ekonomi Nasional (Susenas) menunjukkan bahwa lebih dari $60 \%$ masyarakat melakukan pengobatan sendiri (swamedikas). Menurut Kementerian Kesehatan tahun 2013 , proporsi masyarakat yang menyimpan obat keras tanpa resep mencapai $81,9 \%$ diantaranya termasuk antibiotik.

Penggunaan obat dengan resep dokter juga harus dilakukan secara tepat oleh pasien. Jika cara penggunaan tidak diinformasikan dengan baik oleh tenaga kesehatan, pasien dapat melakukan kesalahan. Maka dari itu pada tahun 2015, Kementerian Kesehatan melalui Direktorat Jenderal Bina Kefarmasian dan Alat Kesehatan meluncurkan GeMa CerMat atau Gerakan Masyarakat Cerdas Menggunakan Obat dalam rangka upaya promotif dan preventif dalam penggunaan obat yang merupakan bagian dari upaya kesehatan masyarakat.

Menurut Direktorat Bina Farmasi Komunitas dan Klinik tahun 2007, apoteker memiliki peran dalam mengoptimalkan terapi dengan cara mencegah dan memecahkan masalah terkait obat (Drug Related Problem). Pasien yang memiliki pengetahuan cukup tentang obat akan menunjukkan peningkatan kepatuhan pada regimen obat yang diterima sehingga akan meningkatkan hasil terapi.

Banyak penelitian di Indonesia menunjukkan bahwa pemberian konseling farmasi dapat meningkatkan kualitas hidup pasien dan lebih menguntungkan dari segi farmakoekonomi. Berdasarkan berita yang dimuat pada Buletin Infarkes Edisi III Mei -Juni 2015, saat ini mash banyak rumah sakit yang belum melakukan pelayanan kefarmasian sesuai standar, dimana apoteker sering terjebak pada padatnya tugas manajemen pengelolaan obat, yang menyebabkan apoteker kurang fokus pada pelayanan kefarmasian sehingga sulit berkomunikasi dengan dokter secara profesional.

Di sebuah RS di Kalimantan Timur dijumpai $88,6 \%$ pasien diabetes mellitus mengalami DRP dengan masalah terbanyak adalah adanya indikasi penyakit yang tidak diterapi secara memadai. Karena itu, pelayanan farmasi klinik sebenarnya dapat mengurangi kejadian DRP tersebut, dan lebih jauh dapat meningkatkan hasil terapi pasien. Intervensi farmasis dalam hal pemberian konseling pada pasien diabetes mellitus berhasil meningkatkan hasil terapi dan kualitas hidup pasien. Demikian pula pada pasien hipertensi di sebuah RS di Jawa Tengah, konseling oleh farmasis dapat meningkatkan pencapaian target tekanan darah yang diinginkan sehingga kualitas hidup pasien juga meningkat.

\section{Kesimpulan}

Oleh karena itu, dapat disimpulkan bahwa peran apoteker dalam PC memegang peranan penting sebagai upaya peningkatan kualitas hidup pasien melalui terapi yang lebih costeffectiveness dari segi farmakoekonomi khususnya untuk penatalaksanaan pada penyakit degeneratif. 


\section{Daftar Pustaka}

Direktorat Bina Farmasi Komunitas dan Klinik, 2007, Pedoman Konseling Pelayanan Kefarmasian di Sarana Kesehatan, Departemen Kesehatan Republik Indonesia, Jakarta, hal.1.

Direktorat Jenderal Bina Kefarmasian dan Alat Kesehatan Kementerian Kesehatan RI, 2015, Buletin INFARKES (Informasi Kefarmasian dan Alat Kesehatan) : Pentingnya Informasi Obat bagi Masyarakat, Edisi III, Redaksi Infarkes, Jakarta Selatan, hal. 5 dan 7.

Direktorat Jenderal Bina Kefarmasian dan Alat Kesehatan, 2013, Pedoman Penerapan Kajian Farmakoekonomi, Kementerian Kesehatan Republik Indonesia, Jakarta, hal. 23-25.

Maxwell, et al, 2013, Cost-Utility Analysis of Pharmacutical Care Intervention Versus Usual Care in Management of Nigerian Patients with Type 2 Diabetes,Value in Health Regional Issues. Volume 2, Issue 2, September-October 2013, Pages 189198. http://dx.doi.org/10.1016/j.vhri.2013.06.009

Thompson, B. T., and David Schoenfeld, 2007, Proceding of The American Thoracic Society Volume 4: Usual Care as The Control Group in Clinical Trials of Nonpharmacologic Interventions, NCBI, US National Library of Medicine National Institute of Health, United States of America, p. 577.

Rikomah S. E., 2016, Farmasi Klinik, Penerbit Deepublish CV Budi Utama, Yogyakarta, hal 16.

Artikel ini telah terbit secara online di http://farmasetika.com/2016/12/03/apoteker-berperanpenting-dalam-membantu-masvarakat-menurunkan-biava-terapi/ 